\title{
Diabetes and Alzheimer's disease: A link not as simple as it seems
}

\author{
Isabel H. Salas ${ }^{1,2, ~ *, ~ B a r t ~ D e ~ S t r o o p e r ~ 1,2,3 ~}$
}

(1) VIB Center for Brain and Disease Research, Leuven, Belgium

(2) KU Leuven Department for Neurosciences. KU Leuven, Leuven, Belgium.

(3) UK Dementia Research Institute (DRI-UK), ION UCL, London, UK.

* Corresponding author: isalashernandez@salk.edu

Type 2 diabetes mellitus (T2DM) is associated with an increased risk to develop Alzheimer disease (AD), however, the underlying mechanisms for this association are still unclear. In this review we will provide a critical overview of the major findings coming from clinical studies and animal models.

\section{Introduction}

The majority of Alzheimer's disease (AD) cases have a sporadic origin, although the genetic background determines strongly the risk of $\mathrm{AD}$, even for sporadic cases [1]. Very little is currently known about the triggering factors of this destructive 
neurodegenerative disorder [2], apart from ageing which is the most important factor for the manifestation of late-onset $\mathrm{AD}$ [3]. Besides ageing, metabolic disorders including type 2 diabetes mellitus (T2DM) has also been associated with an increased risk to develop dementia [4], however, the underlying mechanisms responsible for this association are still controversial.

Given the vast increase of incidence of $\mathrm{AD}$ and metabolic disorders in the aged population $[2,5]$, a better understanding of the potential link between these two disorders is essential. In this review we will critically analyze the major findings coming from clinical and preclinical studies.

\section{Diabetes and Alzheimer's disease: What can we learn from clinical studies?}

Diabetes is a very complex metabolic disorder characterized by a rise in blood glucose levels due to an altered insulin production by pancreatic cells (Type 1) or an impaired insulin response (Type 2) [6]. The chronic hyperglycemia and insulin resistance found in diabetic patients is commonly associated with vascular complications which eventually lead to alterations in the kidney (nephropathy), retina (retinopathy) and peripheral nerves (neuropathy), among other problems [7]. Not surprisingly, besides the abnormalities in peripheral organs, diabetic patients also show structural and functional changes in the central nervous system.

In fact, several studies suggest that there is an increased risk to develop cognitive impairments in patients with diabetes [8]. Type 1 diabetic patients display defects in information processing, psychomotor efficiency, attention, and cognitive flexibility [9].

The effect of type 2 diabetes mellitus (T2DM) in cognition is more controversial: the Maastricht study showed that patients with T2DM performed worse in different cognitive domains including memory, processing speed and executive function, compared to individuals with normal glucose metabolism [10]. In contrast, the New 
Mexico elder Health Survey could not find a significant reduction in the cognitive function in patients with T2DM compared with participants with normal glucose tolerance. [11].

Different population-based cohorts studies have also suggested an increased risk to develop dementia in T2DM patients [4]. The Rotterdam study was the pioneer report showing almost a two-fold increase risk of dementia, mainly $\mathrm{AD}$ and vascular dementia, in patients with T2DM [12]. Since then, many other studies worldwide have consistently shown an increased risk to develop dementia in the T2DM population [13-15]: Schnaider et al. reported that midlife diabetes is a risk factor to develop dementia three decades later in a population of Jewish male civil servants [14]. The Rochester study monitored 1,455 subjects with adult onset diabetes mellitus and they showed a 1.6 fold increased risk of all types of dementia [15]. The Honolulu-Asia aging study showed that diabetes increased the risk of $\mathrm{AD} 1.8$ fold in a population-based cohort of more than 2500 Japanese-American men [16].

Nowadays, despite more than 2000 pubmed papers published on $\mathrm{AD}$ and diabetes, the underlying link between these two disorders is still unclear. The major mechanisms suggested are: hyperglycemia, vascular abnormalities, altered amyloidosis and impaired insulin signaling. However, the observations coming from clinical studies are highly controversial and have failed to elucidate clear pathways responsible for the increased risk of dementia in T2DM patients.

In this review we will make a critical analysis of the different mechanisms suggested in the literature.

\section{a) Alterations in glucose metabolism}

Diabetes is linked to peripheral hyperglycemia. However, how the rise in blood glucose affects brain function is currently unknown [17]. 
Yaffe et al. showed an association between glycosylated hemoglobin levels and the risk to develop $\mathrm{AD}$ or dementia in a group of more than 1900 postmenopausal women [18]. The Maastricht study also reported a correlation between blood glucose levels and a lower processing speed and executive function in patients using cross-sectional data from more than 2500 participants. However, the same study could not find an association between hyperglycemia and impaired memory function [10]. Scott et al. [19] and the Rotterdam study [20] also failed to demonstrate a correlation between elevated glucose levels or glucose intolerance and worse cognitive function in an older population. In line with the latter results, an intensive glycemic therapeutic strategy in patients with T2DM had no positive effects in cognitive outcomes [21].

On the other hand, T2DM patients with mild cognitive impairment (MCI) showed a general reduction in brain $[18 \mathrm{~F}]$-fluorodeoxyglucose (FDG) uptake in gray and white matter [22]. Insulin resistance has also been associated with a reduced cerebral glucose metabolic rate in frontal, temporal-parietal, and cingulate regions in patients with T2DM [23,24].

Interestingly, brain hypometabolism (observed by FDG uptake) is associated with an increased risk for $\mathrm{AD}$ and can be observed years before the dementia onset in the same brain regions affected in T2DM patients $[25,26]$. Thus, the reduced cerebral glucose metabolic rate observed in diabetic patients could be a predisposing factor for $\mathrm{AD}$ and MCI [22].

\section{b) Vascular and structural brain abnormalities}

T2DM is linked to alterations in cerebral microvasculature, including amyloid angiopathy [16,27]. The disorder is also associated with increased number of brain infarcts [28]. T2DM is an important risk factor for ischemic stroke [29]. Other studies have associated chronic hyperglycemia with cerebral microvascular remodeling [30].

Magnetic resonance imaging (MRI) studies revealed loss in brain volume in patients with T2DM [31]. Particularly, brain atrophy was detected in hippocampal and cortical 
brain regions, which can influence the development of AD pathology [32-34]. However, the loss of brain volume does not imply neurodegeneration, and can be due to different pathological processes including loss of glial cells, axons, or white matter shrinkage [27]. In fact, diffusion tensor imaging (DTI) (a MRI technique that detects alterations in white matter tissue) has revealed white matter abnormalities in T2DM patients that correlates with cognitive dysfunction [35]. Moreover, reduced functional connectivity has also been observed in patients with T2DM [36].

\section{c) Impaired insulin signaling in the brain}

Another important mechanism suggested to link dementia and cognitive dysfunction to T2DM is insulin resistance. For years, the brain was considered an insulininsensitive organ, as brain glucose metabolism is largely regulated in an insulinindependent manner [37]. Yet, in the last decades, strong evidences have demonstrated an important role of insulin in the central nervous system (CNS), mainly affecting feeding and cognitive behavior [38]. Mouse experiments suggest that most of the insulin present in the brain is transported from the periphery across the blood brain barrier (BBB) by a receptor-mediated process that can be saturated [39]. Wallum et al. demonstrated in the late $80^{\prime}$ that intravenous insulin infusions increased the levels of insulin in the cerebrospinal fluid (CSF) of eight healthy men [40]. However, the effect of chronic peripheral hyperinsulinemia and insulin resistance in the brain insulin pathway is still not clear.

Liu et al. showed a significant decrease of the PI3K/AKT pathway in the autopsied frontal cortices from T2DM patients compared to heathy controls, suggesting the presence of central insulin resistance associated with diabetes [41]. On the other hand, post-mortem studies have also shown disturbances in the brain insulin signaling in $\mathrm{AD}$ patients. However, these findings are still controversial [42]. i.e.: some groups reported reduced mRNA levels of brain insulin, and insulin receptor (IR) in $\mathrm{AD}$ brains compared to controls [43], while others showed no significant differences 
in IR protein levels or phosphorylation state [44]. The most convincing change in the insulin pathway observed in $\mathrm{AD}$ patients is a reduction of insulin receptor substrate (IRS) levels, accompanied by an increased IRS-1 serine phosphorylation (marker of insulin resistance) [45]. Nevertheless, physiological brain aging is also associated with changes in central brain insulin [46], suggesting that these insulin alterations are not a specific hallmark of neurodegenerative brains. In fact, Frolich et al. reported a reduction of brain insulin levels in $\mathrm{AD}$ patients that was equal to age-matched controls [47].

Considering the role of insulin in cognition, dysregulation of the brain insulin pathway could be responsible for the cognitive impairments found in $\mathrm{AD}$ and T2DM patients. Supporting this hypothesis, pilot clinical trials with intranasal brain insulin delivery have shown improvements in verbal memory and story recall in patients with MCI and AD [48]. Intranasal insulin delivery was used to avoid the systemic side effects of insulin and no major aversive effects were reported [49].

\section{d) Altered amyloidosis and Tau phosphorylation}

Several in vitro studies have proposed a link between impaired insulin signaling and the amyloid cascade, which could explain the increased risk for $\mathrm{AD}$ in diabetic patients. Firstly, one of the proteins potentially involved in $A B$ clearance and degradation is the insulin degrading enzyme (IDE), a metalloprotease that also degrades insulin [50,51]. Postmortem analysis from AD patients suggests lower levels of IDE in the brain [52]. In addition, insulin can also regulate Tau phosphorylation via de PI3K/AKT pathway. AKT activation inhibits the glycogen synthase kinase 38 (GSK 3B), which is the major kinase involved in Tau phosphorylation [53,54]. Diabetes and impaired glucose metabolism have also been associated with accumulation of glycated Tau or amyloid-beta. Glycation might enhance aggregation of these proteins [55]. However, the link between altered insulin signaling and amyloidosis in vivo, is still highly controversial. On the one hand, postmortem analysis from the Hisayama 
study suggested a correlation between hyperglycemia and hyperinsulinemia with an increased amyloid load, but no link with neurofibrillary tangles [56]. On the other hand, the Baltimore longitudinal study showed no significant correlation between amyloid load (assessed in vivo using Pittsburgh Compound B (C-PiB) positron emission tomography (PET) studies) and either glucose intolerance or insulin resistance [57]. In addition, Roberts et al. also reported no differences in the C-PiB retention ratio between diabetic and non-diabetic patients [24]. Other post-mortem studies even suggest a reduced AD-type pathology in T2DM patients [58,59].

Altogether, most of the current evidence suggest that T2DM does not accelerate the development of the core neuropathological features of $\mathrm{AD}$ : amyloid plaques and neurofibrillary tangles [60].

\section{What can we learn from animal models?}

During the last decades, many groups have tried to investigate the mechanisms underlying the link between diabetes and dementia, using animal models. As T2DM is usually associated with obesity and other comorbidities, the most widely used models for T2DM are obese animals. Obesity and T2DM can be triggered by either genetic manipulations such as disruptions in leptin (ob/ob mice) or leptin receptor (db/db mice or Zucker rats) [61], or by special diet treatments. Another commonly used method for the induction of diabetes is the streptozotozin (STZ) injection, which kills the pancreatic 8 -cells triggering defects in insulin production and glucose metabolism similar to the ones observed in diabetic patients [62]

These diet-induced models, proposed as obesity induced by environmental factors, are considered more accurate models mimicking the T2DM human condition [63]. These models usually display hyperglycemia, glucose intolerance and insulin resistance [64].Most of the diets used for these studies are based on higher intake of fat, glucose, cholesterol or different combinations of the three [65]. However, the composition and duration of the diet exposure differ from one study to another, making it difficult to 
achieve general conclusions. In addition, metabolic responses to high fat diet feeding can be very heterogeneous even within the same mouse strain [66].

Given the number of the different models used, the outcomes from these studies are highly variable. Hence, similarly to the situation in humans, the effect of T2DM-like alterations on brain function remains unclear and controversial. Several potential underlying factors have been discussed in the literature. Here, we will summarize what we consider the most important ones.

\section{a) Hyperglycemia}

Chronic hyperglycemia is associated with increased levels of reactive oxygen species (ROS), which is not only responsible for the B-cells deterioration and development of insulin resistance, but also affects brain functions [67]. The brain is particularly vulnerable to oxidative damage due to its high oxygen consumption [68]. Different studies in rodents have shown that high fat diet treatment increased oxidative stress in the brain [69-71]. Another group also demonstrated a deleterious effect of acute hyperglycemia (induced by a single STZ injection) in a rat model of lacunar stroke [72].

However, hyperglycemia is usually accompanied by other comorbidies including insulin resistance, obesity, systemic inflammation, etc. Therefore, it is very difficult to dissect out the specific effect of hyperglycemia itself on brain function. To circumvent this problem, the group from Prof. Holtzman used glycemic clamps in a transgenic mouse model for $\mathrm{AD}$, and measured changes of brain metabolites using in vivo microdialysis [73]. This study elegantly showed that acute peripheral hyperglycemia raises hippocampal interstitial fluid (ISF) glucose and amyloid beta levels. Authors claimed that the increase in $A B$ presumably happened as a consequence of a glucose-induced increased in neuronal activity. 


\section{b) Central insulin resistance in T2DM and AD animal models}

In the last decades, several groups have tried to elucidate whether the peripheral insulin resistance found in diabetic patients, also affects the central insulin pathway using animal models. Yet, the outcomes from these studies is still under discussion.

Some groups claimed a clear link between peripheral and central insulin resistance. Ho et al. for instance revealed alterations in the brain insulin pathway upon dietinduced hyperinsulinemia, including reduced insulin receptor phosphorylation and activation of the downstream pathway and decreased IDE levels [74]. Arnold et al. also reported insulin insensitivity in the frontal cortex from C57BL/6J young mice after 17 days of diet treatment [75]. Another study even suggested that a single intraperitoneal insulin injection is able to rescue amyloidosis and cognitive impairments induced by the high fat diet treatment in $3 \times \mathrm{Tg}-\mathrm{AD}$ mice [76].

In contrast, our group has shown that 10 months of high fat diet treatment did not affect hippocampal insulin sensitivity or the downstream insulin pathway [77]. Supporting our observations, the group from Prof. Holtzman also reported no changes in brain ISF or CFS insulin levels in response to peripheral hyperinsulinemia induced with hyperinsulinemic-euglycemic clamps [42].

$\mathrm{AD}$ itself has been suggested a risk factor for diabetes and metabolic alterations as well [78]. This is mainly based on work in mouse models for AD. Different groups have reported peripheral insulin resistance and signs of T2DM including obesity, hyperglycemia and hyperinsulinemia in such aged models $[79,80]$. However, it is not clear whether these mice develop central insulin resistance (i.e. whether their brains becomes insensitive to insulin). On the one hand, Ho et al. proposed that Tg2576 and $3 \mathrm{xTg}-\mathrm{AD}$ models develop central insulin signaling dysregulation prior to peripheral insulin resistance [81]. In contrast, Stanley et al. showed by direct central insulin delivery, that the brain from old APP/PS1 mice is still responsive to insulin even in the presence of aberrant amyloidosis [42]. 


\section{c) Diabetes mellitus and amyloidosis}

To study the potential link between T2DM and amyloidosis in vivo, most of the groups used transgenic $\mathrm{AD}$ models that already show amyloid plaques aggregation and analyzed whether a high fat diet treatment altered the levels of amyloid in the brain. The conclusions from these studies are highly variable depending on the animal model used or the type of diet treatment $[71,82,83]$. However, even when using the same mouse model (3xTg-AD) and the same diet composition (60\% Kcal from fat), one group reported an increase of amyloid beta levels [76], while the other did not [84].

Some studies also showed different outcomes depending on the duration of the diet. i.e.: Vandal et al. reported increased levels of soluble AB40 and AB42 in the cerebral cortex after 9 but not 4 months of diet treatment [76]. Busquets et al. even suggested de novo plaques aggregation in a C57BL/6J wild type background [85]. In contrast, in our group we used an APP knock-in model which does not develop amyloid plaques, but contained the Swedish mutation that cause AD in humans. In this model, we could not trigger amyloid alterations even after 16 months of high fat diet treatment [77].

In summary, in the last years it has been commonly accepted that metabolic disorders such as obesity and insulin resistance have a detrimental effect on brain amyloidosis. However, the in vivo data in human and mice do not support consistently this hypothesis $[71,77,84]$. In addition, as discussed above, clinical studies also support a lack of correlation between metabolic disturbances and an increased amyloid load [24,57].

\section{d) Others}

Besides the mechanisms mentioned here, there are several other alterations occurring in both, $\mathrm{T} 2 \mathrm{DM}$ and $\mathrm{AD}$, that may also be important to link the two disorders. For example, mitochondrial dysfunction as a consequence of increased oxidative stress has been suggested to be a key contributing factor to diabetes and AD pathology [86]. 
Moreria et al. showed brain mitochondrial dysfunction in old diabetic rats [87]. However, another group reported no defects in brain mitochondria after 1 year of high fat diet treatment in Wister rats [88]. Interestingly, Carvalho et al. found similar mitochondrial alterations in the brain from WT mice fed with high sucrose water, and 3xTg-AD mice [89]. In addition, a mitochondria-targeted antioxidant drug (mitoQ) prevents loss of spatial memory in $3 \times \mathrm{Tg}-\mathrm{AD}$ mice [90].

Neuroinflammation also plays an essential role in the pathogenesis of $\mathrm{AD}$ and might also be affected in T2DM. Obesity, an important risk factor for T2DM and AD [91,92], is associated with a chronic systemic inflammation characterized by the release of pro-inflammatory cytokines [93] and might be associated with inflammation in the brain [94]. In fact, Buckman et al. showed that high fat diet treatment induced recruitment of peripheral immune cells into the CNS [95]. Other studies have also reported an increased gliosis and increased levels of pro-inflammatory cytokines upon high fat diet treatment in rodent models [84,96]. However, our group could not detect changes in pro-inflammatory cytokines or gliosis after 18 months of high fat diet treatment in an APP knock-in model [77].

Finally, misfolded amyloid aggregation is another common pathology in diabetes and $\mathrm{AD}$ : amyloid-beta aggregates in the brain from $\mathrm{AD}$ patients, while islet amyloid polypeptide (IAPP) accumulates in pancreatic cells from T2DM patients. MorenoGonzalez et al. proposed that IAPP present in diabetic patients may act as a seed promoting the misfolding and aggregation of the amyloid-beta peptides [97]. In fact, it has been shown that both aggregates colocalized in brain parenchyma deposits [97,98].

\section{Conclusions and future directions}

Epidemiological studies have provided evidence for a link between diabetes and an increased risk to develop dementia. However, in spite of several proposed mechanisms for this association, we are not able to make final conclusions with regard to what 
specific metabolic alterations could be responsible for this increased predisposition to dementia.

The high heterogeneity between the different cases of $\mathrm{AD}$ and $\mathrm{T} 2 \mathrm{DM}$, and the effects of aging on the CNS and peripheral organs, make it very complicated to dissect the specific mechanisms responsible for a general association observed in populationbased cohort studies. Given the fact that both disorders are highly heterogeneous, it is likely that the link between the two is a consequence of a combination of different molecular, cellular and systemic factors which are difficult to unravel. Caution when proposing specific mechanisms or treatments seems indicated.

\section{References}

[1] Gatz M, Reynolds CA, Fratiglioni L, Johansson B, Mortimer JA, Berg S, Fiske A, Pedersen NL (2006) Role of Genes and Environments for Explaining Alzheimer Disease. Arch. Gen.

Psychiatry 63, 168.

[2] Holtzman DM, Morris JC, Goate AM (2011) Alzheimer's Disease: The Challenge of the Second Century. Sci. Transl. Med. 3, 77sr1-77sr1.

[3] Swerdlow RH (2011) Brain aging, Alzheimer's disease, and mitochondria. Biochim. Biophys. Acta 1812, 1630-9.

[4] Biessels GJ, Staekenborg S, Brunner E, Brayne C, Scheltens P (2006) Risk of dementia in diabetes mellitus: a systematic review. Lancet Neurol. 5, 64-74.

[5] Alberti KGMM, Eckel RH, Grundy SM, Zimmet PZ, Cleeman JI, Donato KA, Fruchart JC, James WPT, Loria CM, Smith SC (2009) Harmonizing the metabolic syndrome: A joint interim statement of the international diabetes federation task force on epidemiology and prevention; National heart, lung, and blood institute; American heart association; World heart federation; International . Circulation 120, 1640-1645.

[6] Akter K, Lanza EA, Martin SA, Myronyuk N, Rua M, Raffa RB (2011) Diabetes mellitus and Alzheimer's disease: Shared pathology and treatment? Br. J. Clin. Pharmacol. 71, 365-376.

[7] Donaghue KC, Chiarelli F, Trotta D, Allgrove J, Dahl-Jorgensen K (2009) Microvascular and macrovascular complications associated with diabetes in children and adolescents. Pediatr. 
Diabetes 10, 195-203.

[8] Kodl CT, Seaquist ER (2008) Cognitive dysfunction and diabetes mellitus. Endocr. Rev. 29, $494-511$.

[9] Brands AMA, Biessels GJ, de Haan EHF, Kappelle LJ, Kessels RPC (2005) The effects of type 1 diabetes on cognitive performance: a meta-analysis. Diabetes Care 28, 726-35.

[10] Geijselaers SLC, Sep SJS, Claessens D, Schram MT, van Boxtel MPJ, Henry RMA, Verhey FRJ, Kroon AA, Dagnelie PC, Schalkwijk CG, van der Kallen CJH, Biessels GJ, Stehouwer CDA (2017) The Role of Hyperglycemia, Insulin Resistance, and Blood Pressure in DiabetesAssociated Differences in Cognitive Performance-The Maastricht Study. Diabetes Care 40, $1537-1547$.

[11] Lindeman RD, Romero LJ, LaRue A, Yau CL, Schade DS, Koehler KM, Baumgartner RN, Garry PJ, New Mexico Elder Health Survey (2001) A biethnic community survey of cognition in participants with type 2 diabetes, impaired glucose tolerance, and normal glucose tolerance: the New Mexico Elder Health Survey. Diabetes Care 24, 1567-72.

[12] Ott A, Stolk RP, van Harskamp F, Pols HA, Hofman A, Breteler MM (1999) Diabetes mellitus and the risk of dementia: The Rotterdam Study. Neurology 53, 1937-42.

[13] Yoshitake T, Kiyohara Y, Kato I, Ohmura T, Iwamoto H, Nakayama K, Ohmori S, Nomiyama K, Kawano H, Ueda K (1995) Incidence and risk factors of vascular dementia and Alzheimer's disease in a defined elderly Japanese population: the Hisayama Study. Neurology 45, 1161-8.

[14] Schnaider Beeri M, Goldbourt U, Silverman JM, Noy S, Schmeidler J, Ravona-Springer R, Sverdlick A, Davidson M (2004) Diabetes mellitus in midlife and the risk of dementia three decades later. Neurology 63, 1902-7.

[15] Leibson CL, Rocca WA, Hanson VA, Cha R, Kokmen E, O'Brien PC, Palumbo PJ (1997) Risk of dementia among persons with diabetes mellitus: a population-based cohort study. Am. J. Epidemiol. 145, 301-8.

[16] Peila R, Rodriguez BL, Launer LJ, Honolulu-Asia Aging Study (2002) Type 2 diabetes, APOE gene, and the risk for dementia and related pathologies: The Honolulu-Asia Aging Study.

Diabetes 51, 1256-62.

[17] Crane PK, Walker R, Hubbard RA, Li G, Nathan DM, Zheng H, Haneuse S, Craft S, Montine TJ, Kahn SE, McCormick W, McCurry SM, Bowen JD, Larson EB (2013) Glucose Levels and Risk of Dementia. N. Engl. J. Med. 369, 540-548. 
[18] Yaffe K, Blackwell T, Whitmer R a, Krueger K, Barrett Connor E (2006) Glycosylated hemoglobin level and development of mild cognitive impairment or dementia in older women. J. Nutr. Health Aging 10, 293-295.

[19] Scott RD, Kritz-Silverstein D, Barrett-Connor E, Wiederholt WC (1998) The association of non-insulin-dependent diabetes mellitus and cognitive function in an older cohort. J. Am. Geriatr. Soc. 46, 1217-22.

[20] Euser SM, Sattar N, Witteman JCM, Bollen ELEM, Sijbrands EJG, Hofman A, Perry IJ, Breteler MMB, Westendorp RGJ, PROSPER and Rotterdam Study for P and the R (2010) A prospective analysis of elevated fasting glucose levels and cognitive function in older people: results from PROSPER and the Rotterdam Study. Diabetes 59, 1601-7.

[21] Launer LJ, Miller ME, Williamson JD, Lazar RM, Gerstein HC, Murray AM, Sullivan M, Horowitz KR, Ding J, Marcovina S, Lovato LC, Lovato J, Margolis KL, Connor PO, Lipkin EW, Hirsh J (2012) Effects of randomization to intensive glucose lowering on brain structure and function in type 2 diabetes ACCORD Memory in Diabetes Study. 10, 969-977.

[22] Li W, Risacher SL, Huang E, Saykin AJ, Alzheimer's Disease Neuroimaging Initiative F the ADN (2016) Type 2 diabetes mellitus is associated with brain atrophy and hypometabolism in the ADNI cohort. Neurology 87, 595-600.

[23] Baker LD, Cross DJ, Minoshima S, Belongia D, Watson GS, Craft S (2011) Insulin resistance and Alzheimer-like reductions in regional cerebral glucose metabolism for cognitively normal adults with prediabetes or early type 2 diabetes. Arch. Neurol. 68, 51-7.

[24] Roberts RO, Knopman DS, Cha RH, Mielke MM, Pankratz VS, Boeve BF, Kantarci K, Geda YE, Jack CR, Petersen RC, Lowe VJ (2014) Diabetes and Elevated Hemoglobin A1c Levels Are Associated with Brain Hypometabolism but Not Amyloid Accumulation. J. Nucl. Med. 55, 759764.

[25] Minoshima S, Giordani B, Berent S, Frey KA, Foster NL, Kuhl DE (1997) Metabolic reduction in the posterior cingulate cortex in very early Alzheimer's disease. Ann. Neurol. 42, 85-94.

[26] Langbaum JBS, Chen K, Lee W, Reschke C, Bandy D, Fleisher AS, Alexander GE, Foster NL, Weiner MW, Koeppe RA, Jagust WJ, Reiman EM, Alzheimer's Disease Neuroimaging Initiative (2009) Categorical and correlational analyses of baseline fluorodeoxyglucose positron emission tomography images from the Alzheimer's Disease Neuroimaging Initiative (ADNI). Neuroimage 45, 1107-1116.

[27] Biessels GJ, Reijmer YD (2014) Brain changes underlying cognitive dysfunction in diabetes: 
What can we learn from MRI? Diabetes 63, 2244-2252.

[28] Vermeer SE, Den Heijer T, Koudstaal PJ, Oudkerk M, Hofman A, Breteler MMB, Rotterdam Scan Study (2003) Incidence and risk factors of silent brain infarcts in the population-based Rotterdam Scan Study. Stroke 34, 392-6.

[29] Ergul A, Kelly-Cobbs A, Abdalla M, Fagan SC (2012) Cerebrovascular complications of diabetes: focus on stroke. Endocr. Metab. Immune Disord. Drug Targets 12, 148-58.

[30] Hou Q, Zuo Z, Michel P, Zhang Y, Eskandari A, Man F, Gao Q, Johnston KC, Wintermark M (2013) Influence of Chronic Hyperglycemia on Cerebral Microvascular Remodeling: An In Vivo Study Using Perfusion Computed Tomography in Acute Ischemic Stroke Patients. Stroke 44, $3557-3560$.

[31] de Bresser J, Tiehuis AM, van den Berg E, Reijmer YD, Jongen C, Kappelle LJ, Mali WP, Viergever MA, Biessels GJ, Utrecht Diabetic Encephalopathy Study Group (2010) Progression of Cerebral Atrophy and White Matter Hyperintensities in Patients With Type 2 Diabetes.

Diabetes Care 33, 1309-1314.

[32] den Heijer T, Vermeer SE, van Dijk EJ, Prins ND, Koudstaal PJ, Hofman A, Breteler MMB (2003) Type 2 diabetes and atrophy of medial temporal lobe structures on brain MRI.

Diabetologia 46, 1604-1610.

[33] Schmidt R, Launer LJ, Nilsson L-G, Pajak A, Sans S, Berger K, Breteler MM, de Ridder M, Dufouil C, Fuhrer R, Giampaoli S, Hofman A, CASCADE Consortium (2004) Magnetic resonance imaging of the brain in diabetes: the Cardiovascular Determinants of Dementia (CASCADE) Study. Diabetes 53, 687-92.

[34] Gold SM, Dziobek I, Sweat V, Tirsi A, Rogers K, Bruehl H, Tsui W, Richardson S, Javier E, Convit A (2007) Hippocampal damage and memory impairments as possible early brain complications of type 2 diabetes. Diabetologia 50, 711-719.

[35] Reijmer YD, Brundel M, de Bresser J, Kappelle LJ, Leemans A, Biessels GJ, Utrecht Vascular Cognitive Impairment Study Group on behalf of the UVCIS (2013) Microstructural white matter abnormalities and cognitive functioning in type 2 diabetes: a diffusion tensor imaging study. Diabetes Care 36, 137-44.

[36] Musen G, Jacobson AM, Bolo NR, Simonson DC, Shenton ME, McCartney RL, Flores VL, Hoogenboom WS (2012) Resting-State Brain Functional Connectivity Is Altered in Type 2 Diabetes. Diabetes 61, 2375-2379. 
[37] McEwen BS, Reagan LP (2004) Glucose transporter expression in the central nervous system: relationship to synaptic function. Eur. J. Pharmacol. 490, 13-24.

[38] Banks WA, Owen JB, Erickson MA (2012) Insulin in the brain: there and back again. Pharmacol. Ther. 136, 82-93.

[39] Banks WA, Jaspan JB, Kastin AJ (1997) Selective, physiological transport of insulin across the blood-brain barrier: novel demonstration by species-specific radioimmunoassays. Peptides 18, 1257-62.

[40] WALLUM BJ, TABORSKY GJ, PORTE D, FIGLEWICZ DP, JACOBSON L, BEARD JC, WARD WK, DORSA D (1987) Cerebrospinal Fluid Insulin Levels Increase During Intravenous Insulin Infusions in Man*. J. Clin. Endocrinol. Metab. 64, 190-194.

[41] Liu Y, Liu F, Grundke-Iqbal I, Iqbal K, Gong C-X (2011) Deficient brain insulin signalling pathway in Alzheimer's disease and diabetes. J. Pathol. 225, 54-62.

[42] Stanley M, Macauley SL, Holtzman DM (2016) Changes in insulin and insulin signaling in Alzheimer's disease: cause or consequence? J. Exp. Med. 213, 1375-1385.

[43] Steen E, Terry BM, Rivera EJ, Cannon JL, Neely TR, Tavares R, Xu XJ, Wands JR, de la Monte SM (2005) Impaired insulin and insulin-like growth factor expression and signaling mechanisms in Alzheimer's disease--is this type 3 diabetes? J. Alzheimers. Dis. 7, 63-80.

[44] Ho L, Yemul S, Knable L, Katsel P, Zhao R, Haroutunian V, Pasinetti GM (2012) Insulin Receptor Expression and Activity in the Brains of Nondiabetic Sporadic Alzheimer's Disease Cases. Int. J. Alzheimers. Dis. 2012, 1-12.

[45] Moloney AM, Griffin RJ, Timmons S, O'Connor R, Ravid R, O’Neill C (2010) Defects in IGF-1 receptor, insulin receptor and IRS-1/2 in Alzheimer's disease indicate possible resistance to IGF-1 and insulin signalling. Neurobiol. Aging 31, 224-243.

[46] Baranowska-Bik A, Bik W (2017) Insulin and brain aging. Prz. menopauzalny= Menopause Rev. 16, 44-46.

[47] Frölich L, Blum-Degen D, Bernstein H-G, Engelsberger S, Humrich J, Laufer S, Muschner D, Thalheimer A, Türk A, Hoyer S, Zöchling R, Boissl KW, Jellinger K, Riederer P (1998) Brain insulin and insulin receptors in aging and sporadic Alzheimer's disease. J. Neural Transm. $105,423$.

[48] Avgerinos KI, Grigorios Kalaitzidis ; Malli A, Dimitrios Kalaitzoglou ; Pavlos ; Myserlis G, Lioutas V-A (2018) Intranasal insulin in Alzheimer's dementia or mild cognitive impairment: 
a systematic review. J. Neurol. 265, 1497-1510.

[49] Reger MA, Craft S (2006) Intranasal insulin administration: A method for dissociating central and peripheral effects of insulin. Drugs of Today 42, 729.

[50] Farris W, Mansourian S, Chang Y, Lindsley L, Eckman EA, Frosch MP, Eckman CB, Tanzi RE, Selkoe DJ, Guenette S (2003) Insulin-degrading enzyme regulates the levels of insulin, amyloid -protein, and the -amyloid precursor protein intracellular domain in vivo. Proc. Natl. Acad. Sci. 100, 4162-4167.

[51] Behl M, Zhang Y, Zheng W (2009) Involvement of insulin-degrading enzyme in the clearance of beta-amyloid at the blood-CSF barrier: Consequences of lead exposure. Cerebrospinal Fluid Res. 6, 11.

[52] Cook DG, Leverenz JB, McMillan PJ, Kulstad JJ, Ericksen S, Roth RA, Schellenberg GD, Jin L-W, Kovacina KS, Craft S (2003) Reduced hippocampal insulin-degrading enzyme in lateonset Alzheimer's disease is associated with the apolipoprotein E-epsilon4 allele. Am. J. Pathol. 162, 313-9.

[53] Avila J, León-Espinosa G, García E, García-Escudero V, Hernández F, DeFelipe J, Garc\&\#xed, a-Escudero V, Hern\&\#xe1, ndez F, lix, DeFelipe J (2012) Tau Phosphorylation by GSK3 in Different Conditions. Int. J. Alzheimers. Dis. 2012, 1-7.

[54] Cross DAE, Alessi DR, Cohen P, Andjelkovich M, Hemmings BA (1995) Inhibition of glycogen synthase kinase-3 by insulin mediated by protein kinase B. Nature $378,785-789$.

[55] Negre-Salvayre A, Salvayre R, Augé N, Pamplona R, Portero-Otín M (2009) Hyperglycemia and Glycation in Diabetic Complications. Antioxid. Redox Signal. 11, 3071-3109.

[56] Matsuzaki T, Sasaki K, Tanizaki Y, Hata J, Fujimi K, Matsui Y, Sekita A, Suzuki SO, Kanba S, Kiyohara Y, Iwaki T (2010) Insulin resistance is associated with the pathology of Alzheimer disease: The Hisayama Study. Neurology 75, 764-770.

[57] Thambisetty M, Metter EJ, Yang A, Dolan H, Marano C, Zonderman AB, Troncoso JC, Zhou Y, Wong DF, Ferrucci L, Egan J, Resnick SM, O’Brien RJ (2013) Glucose Intolerance, Insulin Resistance, and Pathological Features of Alzheimer Disease in the Baltimore Longitudinal Study of Aging. JAMA Neurol. 70, 1167.

[58] Ahtiluoto S, Polvikoski T, Peltonen M, Solomon A, Tuomilehto J, Winblad B, Sulkava R, Kivipelto M (2010) Diabetes, Alzheimer disease, and vascular dementia: A population-based neuropathologic study. Neurology 75, 1195-1202. 
[59] Nelson PT, Smith CD, Abner EA, Schmitt FA, Scheff SW, Davis GJ, Keller JN, Jicha GA, Davis D, Wang-Xia W, Hartman A, Katz DG, Markesbery WR (2009) Human cerebral neuropathology of Type 2 diabetes mellitus. Biochim. Biophys. Acta - Mol. Basis Dis. 1792, $454-469$.

[60] Biessels GJ, Reagan LP (2015) Hippocampal insulin resistance and cognitive dysfunction. Nat. Rev. Neurosci. 16, 660-671.

[61] Gault VA, Kerr BD, Harriott P, Flatt PR (2011) Administration of an acylated GLP-1 and GIP preparation provides added beneficial glucose-lowering and insulinotropic actions over single incretins in mice with Type 2 diabetes and obesity. Clin. Sci. 121, 107-117.

[62] Graham ML, Janecek JL, Kittredge JA, Hering BJ, Schuurman H-J (2011) The streptozotocininduced diabetic nude mouse model: differences between animals from different sources.

Comp. Med. 61, 356-60.

[63] King AJF (2012) The use of animal models in diabetes research. Br. J. Pharmacol. 166, 877894.

[64] Heydemann A, Ahlke (2016) An Overview of Murine High Fat Diet as a Model for Type 2 Diabetes Mellitus. J. Diabetes Res. 2016, 1-14.

[65] Hariri N, Thibault L (2010) High-fat diet-induced obesity in animal models. Nutr. Res. Rev. 23, 270-299.

[66] Burcelin R, Crivelli V, Dacosta A, Roy-Tirelli A, Thorens B (2002) Heterogeneous metabolic adaptation of C57BL/6J mice to high-fat diet. Am. J. Physiol. - Endocrinol. Metab. 282, E834E842.

[67] Kaneto H, Katakami N, Matsuhisa M, Matsuoka T (2010) Role of reactive oxygen species in the progression of type 2 diabetes and atherosclerosis. Mediators Inflamm. 2010, 453892.

[68] Muriach M, Flores-Bellver M, Romero FJ, Barcia JM (2014) Diabetes and the brain: oxidative stress, inflammation, and autophagy. Oxid. Med. Cell. Longev. 2014, 102158.

[69] Balbaa M, Abdulmalek SA, Khalil S (2017) Oxidative stress and expression of insulin signaling proteins in the brain of diabetic rats: Role of Nigella sativa oil and antidiabetic drugs. PLoS One 12, e0172429.

[70] Morrison CD, Pistell PJ, Ingram DK, Johnson WD, Liu Y, Fernandez-Kim SO, White CL, Purpera MN, Uranga RM, Bruce-Keller AJ, Keller JN (2010) High fat diet increases hippocampal oxidative stress and cognitive impairment in aged mice: implications for 
decreased Nrf2 signaling. J. Neurochem. 114, 1581-9.

[71] Studzinski CM, Li F, Bruce-Keller AJ, Fernandez-Kim SO, Zhang L, Weidner AM, Markesbery WR, Murphy MP, Keller JN (2009) Effects of short-term Western diet on cerebral oxidative stress and diabetes related factors in APP $\times$ PS1 knock-in mice. J. Neurochem. 108, 860-866.

[72] Tsai M-J, Lin M-W, Huang Y-B, Kuo Y-M, Tsai Y-H (2016) The Influence of Acute Hyperglycemia in an Animal Model of Lacunar Stroke That Is Induced by Artificial Particle Embolization. Int. J. Med. Sci. 13, 347-56.

[73] Macauley SL, Stanley M, Caesar EE, Yamada SA, Raichle ME, Perez R, Mahan TE, Sutphen CL, Holtzman DM (2015) Hyperglycemia modulates extracellular amyloid- $B$ concentrations and neuronal activity in vivo. J. Clin. Invest. 125, 2463-2467.

[74] Ho L, Qin W, Pompl PN, Xiang Z, Wang J, Zhao Z, Peng Y, Cambareri G, Rocher A, Mobbs C V, Hof PR, Pasinetti GM (2004) Diet-induced insulin resistance promotes amyloidosis in a transgenic mouse model of Alzheimer's disease. FASEB J. 18, 902-4.

[75] Arnold SE, Lucki I, Brookshire BR, Carlson GC, Browne CA, Kazi H, Bang S, Choi B-R, Chen Y, McMullen MF, Kim SF (2014) High fat diet produces brain insulin resistance, synaptodendritic abnormalities and altered behavior in mice. Neurobiol. Dis. 67, 79-87.

[76] Vandal M, White PJ, Tremblay C, St-Amour I, Chevrier G, Emond V, Lefrancois D, Virgili J, Planel E, Giguere Y, Marette A, Calon F (2014) Insulin Reverses the High-Fat Diet-Induced Increase in Brain A and Improves Memory in an Animal Model of Alzheimer Disease.

Diabetes 63, 4291-4301.

[77] Salas IH, Weerasekera A, Ahmed T, Callaerts-Vegh Z, Himmelreich U, D'Hooge R, Balschun D, Saido TC, De Strooper B, Dotti CG (2018) High fat diet treatment impairs hippocampal long-term potentiation without alterations of the core neuropathological features of Alzheimer disease. Neurobiol. Dis.

[78] Diabetes, Increased Risk of Type 2 Diabetes in Alzheimer Disease, Last updated 2004, Accessed on 2004.

[79] Pedersen WA, Flynn ER (2004) Insulin resistance contributes to aberrant stress responses in the Tg2576 mouse model of Alzheimer's disease. Neurobiol. Dis. 17, 500-506.

[80] Vandal M, White P, Chevrier G, Tremblay C, St.-Amour I, Planel E, Marette A, Calon F (2015) Age-dependent impairment of glucose tolerance in the 3xTg-AD mouse model of Alzheimer's 
disease. FASEB J. 29, 4273-4284.

[81] Velazquez R, Tran A, Ishimwe E, Denner L, Dave N, Oddo S, Dineley KT (2017) Central insulin dysregulation and energy dyshomeostasis in two mouse models of Alzheimer's disease. Neurobiol. Aging 58, 1-13.

[82] Ho L, Qin W, Pompl PN, Xiang Z, Wang J, Zhao Z, Peng Y, Cambareri G, Rocher A, Mobbs C V, Hof PR, Pasinetti GM (2004) Diet-induced insulin resistance promotes amyloidosis in a transgenic mouse model of Alzheimer's disease. FASEB J. 18, 902-4.

[83] Petrov D, Pedrós I, Artiach G, Sureda FX, Barroso E, Pallàs M, Casadesús G, Beas-Zarate C, Carro E, Ferrer I, Vazquez-Carrera M, Folch J, Camins A (2015) High-fat diet-induced deregulation of hippocampal insulin signaling and mitochondrial homeostasis deficiences contribute to Alzheimer disease pathology in rodents. Biochim. Biophys. Acta - Mol. Basis Dis. $1852,1687-1699$.

[84] Knight EM, Martins IVA, Gümüsgöz S, Allan SM, Lawrence CB (2014) High-fat diet-induced memory impairment in triple-transgenic Alzheimer's disease (3xTgAD) mice is independent of changes in amyloid and tau pathology. Neurobiol. Aging 35, 1821-32.

[85] Busquets O, Ettcheto M, Pallàs M, Beas-Zarate C, Verdaguer E, Auladell C, Folch J, Camins A (2016) Long-term exposition to a high fat diet favors the appearance of B-amyloid depositions in the brain of C57BL/6J mice. A potential model of sporadic Alzheimer's disease. Mech. Ageing Dev.

[86] Moreira PI, Santos MS, Seiça R, Oliveira CR (2007) Brain mitochondrial dysfunction as a link between Alzheimer's disease and diabetes. J. Neurol. Sci. 257, 206-214.

[87] Moreira PI, Santos MS, Moreno AM, Seiça R, Oliveira CR (2003) Increased vulnerability of brain mitochondria in diabetic (Goto-Kakizaki) rats with aging and amyloid-beta exposure. Diabetes 52, 1449-56.

[88] Jørgensen T, Grunnet N, Quistorff B (2015) One-year high fat diet affects muscle-but not brain mitochondria. J. Cereb. Blood Flow Metab. 35, 943-50.

[89] Carvalho C, Cardoso S, Correia SC, Santos RX, Santos MS, Baldeiras I, Oliveira CR, Moreira PI (2012) Metabolic Alterations Induced by Sucrose Intake and Alzheimer's Disease Promote Similar Brain Mitochondrial Abnormalities. Diabetes 61, 1234-1242.

[90] McManus MJ, Murphy MP, Franklin JL (2011) The Mitochondria-Targeted Antioxidant MitoQ Prevents Loss of Spatial Memory Retention and Early Neuropathology in a Transgenic 
Mouse Model of Alzheimer's Disease. J. Neurosci. 31, 15703-15715.

[91] Haslam D, Sattar N, Lean M (2006) ABC of obesity. Obesity--time to wake up. BMJ 333, 6402.

[92] Beydoun MA, Beydoun HA, Wang Y (2008) Obesity and central obesity as risk factors for incident dementia and its subtypes: a systematic review and meta-analysis. Obes. Rev. 9, 204218.

[93] Gregor MF, Hotamisligil GS (2011) Inflammatory Mechanisms in Obesity. Annu. Rev. Immunol. 29, 415-445.

[94] Guillemot-Legris O, Muccioli GG (2017) Obesity-Induced Neuroinflammation: Beyond the Hypothalamus. Trends Neurosci. 40, 237-253.

[95] Buckman L, Hasty A, Flaherty D, Buckman C, Thompson M, Matlock B, Weller K, Ellacott K (2014) Obesity induced by a high-fat diet is associated with increased immune cell entry into the central nervous system. Brain. Behav. Immun. 35, 33-42.

[96] De Souza CT, Araujo EP, Bordin S, Ashimine R, Zollner RL, Boschero AC, Saad MJA, Velloso LA (2005) Consumption of a Fat-Rich Diet Activates a Proinflammatory Response and Induces Insulin Resistance in the Hypothalamus. Endocrinology 146, 4192-4199.

[97] Moreno-Gonzalez I, Edwards III G, Salvadores N, Shahnawaz M, Diaz-Espinoza R, Soto C (2017) Molecular interaction between type 2 diabetes and Alzheimer's disease through crossseeding of protein misfolding. Mol. Psychiatry 22, 1327-1334.

[98] Jackson K, Barisone GA, Diaz E, Jin L, DeCarli C, Despa F (2013) Amylin deposition in the brain: A second amyloid in Alzheimer disease? Ann. Neurol. 74, 517-526. 